\title{
NUMERACY IN CENTRAL NEW SPAIN DURING THE ENLIGHTENMENT
}

ANDRÉS CALDERÓN-FERNÁNDEZ

UNAM-FE

RAFAEL DOBADO-GONZÁLEZ

Universidad Complutense de Madrid ${ }^{\mathrm{b}}$

ALFREDO GARCÍA-HIERNAUX

DANAE e ICAE (Universidad Complutense de Madrid) ${ }^{c}$

\section{Preliminary version}

\begin{abstract}
This article presents new evidence and analysis on age heaping -a proxy for numeracy and therefore for human capital- in New Spain during the Enlightenment. Human capital plays an important role in economic growth and welfare. It is also one of the dimensions of inequality. Our results are at odds with many of the usual assumptions on which most Mexicanist historiography is based. Age heaping levels of males and females and ethnic groups across locations in Central New Spain are estimated and compared through ad hoc indicators with other countries. We infer that a more empirical emphasis on the institutional legacy of the viceregal period and more attention to human capital since pre-Conquest times will benefit the progress of Hispanic American economic history.
\end{abstract}

JEL Classification: 100, N00, N16

Keywords: Age Heaping, numeracy, human capital, eighteenth-century Mexico, international comparisons.

\footnotetext{
a Departamento de Historia Económica. andrescalderonfernandez@yahoo.com.mex

b Departamento de Economía Aplicada, Estructura e Historia. rdobado@ccee.ucm.es

c Fundamentos del Análisis Económico. agarciah@ucm.es
} 


\section{INTRODUCTION}

Institutions have enjoyed an important, if perhaps somewhat undeserved, role in the explanation of long-term economic growth by economists and economic historians during the last two decades or so. In spite of this, human capital has remained widely accepted as one of the main explanatory variables of economic growth (Crayen and Baten, 2010; Földvári et al., 2012). Thus, Glaeser et al. (2004) offer a convincing answer to Acemoglu et al. $(2001,2002)$, which is very relevant to our purposes. ${ }^{1}$ In turn, Engerman and Sokoloff (2005) attribute great importance to the differences in human capital between Europeans and Aboriginals for explaining inequality in the conquered teerritories. Additionaly, a new scholarship is investigating the place of women in the process of human capital formation (De Moor and Van Zanden, 2010; Baten and De Pleijt, 2018; De Moor, s.d.).

Numeracy may be taken as a reliable proxy for human capital in historical populations (Crayen and Baten, 2010a; Hippe, 2012). Numeracy is defined as the "ability to count, keep records of these counts, and make rational calculations" by Manzel et al. (2012, p. 933). Crayen and Baten (2010a) base their argument on several convincing key points. ${ }^{2}$ Among other advantages, numeracy can be measured. This is because humans do not always know their exact age when asked about it. Paradoxically, the absence of precision regarding their age by individuals in past and present societies makes it possible to estimate numeracy. As explained by A'Hearn et al. (2009, pp. 785-786):

"Approximation in age awareness manifests itself in the phenomenon of 'heaping' in self-reported age data. Individuals lacking certain knowledge of their age rarely state this openly but choose instead a figure they deem

\footnotetext{
1 "The Europeans who settled in the New World may have brought with them not so much their institutions, but themselves, that is, their human capital." Glaeser et al., 2004, p. 274.

2 "Numeracy should be considered as a historical measure of human capital since knowledge about numbers and numeric discipline are even more crucial for economic growth than the ability to sign one's name on a marriage certificate. Numeracy goes hand-in-hand with technological abilities, and it is a necessity for modern commercial economies. For Weber, Sombart, and Schumpeter, numeracy was at the very heart of modern rational capitalism. They traced the latter's roots back to the invention of double-entry bookkeeping in late-medieval Italy." Crayen and Baten, (2010a, p. 83).
} 
plausible. They do not choose randomly but have a systematic tendency to prefer 'attractive' numbers, such as those ending in 5 or 0 , even numbers, or -in some societies- numbers with other specific terminal digits."

Age heaping can be estimated using ad hoc techniques -see next section. Thus, age heaping becomes a convincing indicator of numeracy (Tollnek and Baten, 2017, p. 799). For these, and many other, authors: "The share of persons able to report an exact age is highly correlated with other indicators of human capital, such as literacy and schooling, across countries and over time."

Additionally, as pointed out by $A^{\prime}$ Hearn et al. (2009), the historical sources allowing us to estimate age heaping are comparatively abundant (e.g., census returns, tombstones, necrologies, muster lists, legal records and tax data). This advantage over alternative proxies for human capital is relevant for economic historians of the Early Modern Era. All in all, a wide consensus exists regarding the causal relationship between age heaping, numeracy and human capital formation. ${ }^{3}$

Although a contemporaneous positive correlation between living standards and human capital is not always found, it seems reasonable to assume that in the long or very long run these two dimensions of welfare interact reinforcing each other over time. $^{4}$

Despite its interest, literature on numeracy in the Hispanic world during the Early Modern era is rather scarce. To the best of our knowledge, only Baten and collaborators have studied the topic for Spanish American countries before independence (Baten and Mumme, 2010; Manzel et al. (2012); Juif and Baten, 2013).

\footnotetext{
${ }^{3}$ Recently, some authors have questioned the validity of age heaping as a proxy for human capital formation (A'Hearn et al., 2017; Beltrán et al., 2017). On the contrary, an article as recent as that by Blum and Krauss (2018) still supports the most extended view. Criticism of the use of age heaping as a proxy for human capital ought to be taken into consideration. However, even if, as claimed by A'Hearn et al. (2017), age heaping might be interpreted as an indicator of cultural and institutional modernization rather than as a direct measure of cognitive skills, the fact still remains that it is unlikely that modernization does not positively correlate with human capital accumulation.

${ }^{4}$ Baten et al. (2010) show that the combination of low living standards with high human capital is present in traditional China -or even today, if compared with the OECD countries-. No correlation between age heaping and height is found in a sample of more than 20,000 observations from Central New Spain for circa 1790.
} 
As for Spain, the scarcity of works is even more acute (Álvarez and Ramos 2018 for Castile; Gómez Aznar 2019 for Catalonia and Juif et. al., forthcoming).

We contribute to the limited existing literature analyzing numeracy in late eighteenth-century Central New Spain. Our research is relevant because of the sample size as well as the fact that all ethnic groups and females are included. The comparison with other societies is another asset of our work. The well-known age heaping methodology is used in this paper. Our micro approach allows us to explore a rich data set privileging focus over scope.

Our results partially contradict some of the usual assumptions (be they explicit or, more commonly, implicit), behind mainstream thinking on socioeconomic conditions prevailing in pre-independent Mexico. This is especially the case in terms of what can be described as the "inequality question". This issue was raised in the late 1990s and early 2000s in a series of widespread papers written by Engerman and Sokoloff (1994, 2002 and 2005) and Acemoglu et al. (2002). They depict New Spain, along with most Spanish American countries, as an extreme case of inequality. This "original $\sin ^{\prime}$ would continue to be rooted in the post-independence institutions and constitute the main cause of the development problems (low growth and high inequality) experienced by Spanish America. The enormous influence exerted by this institutionalist approach is somehow surprising since no empirical evidence on inequality is offered for the pre-independent period. ${ }^{5}$

On the contrary, Milanovic et al. (2010) deal with inequality in 28 historical societies (ranging from the first-century Roman Empire to 1947 British-ruled India) in an empirical, although not unproblematic, way. They do so by using mainly social tables and tax censuses to estimate Gini coefficients. They found that inequality in New Spain circa 1790, derived from the Escritos that the bishop Abad y Queipo wrote between 1799 and 1813, was so high that it lay beyond the theoretical maximum represented by the inequality possibility frontier. In this respect, some Mexican historians (e.g., Tanck and Marichal, 2010), based on qualitative evidence, claim that wealth was concentrated in the hands of the Spaniards born in America.

\footnotetext{
${ }^{5}$ Further argumentation in Dobado (2009).
} 
Thus, our results contribute to offer a more nuanced picture of Central New Spain's society in the late viceregal period. Numeracy, proxied by age heaping, is comparable to that of peripheral Europe and much lower than in the backward regions of the world (most of Asia and Africa). Spatial differences within our region are observed, as occurs across Europe. ${ }^{6}$ Inequalities based on ethnicity existed. As could be expected, españoles were at the top of the distribution, indios and mulatos (also classified as negros) at the bottom, while other castas (castizos and mestizos) generally fell in between. ${ }^{7}$ However, these disparities were not significantly larger than those found between the upper and lower strata of core countries in Early Modern Europe, not to mention the Cape Colony around the same time. Nevertheless, geographical heterogeneity is more significant than that caused by ethnicity. A sexual gap is found, but it is not higher than in the European samples for different periods and sometimes it even favors females (as in the city of Oaxaca). Finally, we point out that the comparatively high numeracy levels found in late viceregal times did not lead to a higher GDP per capita in Mexico by $1870 .{ }^{8}$ Thus, we consider that the explanation for the poor results shown by the Mexican economy after independence are to be found rather after 1810 than before.

The rest of this article is organized as follows. After this introduction, it comprises four sections: the first one introduces the concepts of numeracy and age heaping and presents the sources used; the levels of age heaping estimated for three samples belonging to late eighteenth-century Central New Spain (Oaxaca, Mexico City and 24 localities in Central Mexico, including Guanajuato, Queretaro and Tlaxcala) are presented in the following section; the next section focuses on the international

\footnotetext{
${ }^{6}$ See e.g., Hippe and Baten (2011) and Tollnek and Baten (2017).

7 "Racial classifications in New Spain were not strict and totally precise divisions between the different groups. Before the mid-seventeenth century, official documents made little effort to distinguish beyond Spaniards, Indians, and Blacks (Hausberger and Mazín, 2010). Our translation. Any misinterpretation remains our sole responsibility. Nonetheless, by the late eighteenth century, the enlightened spirits of New Spain tried to order and classify their environment, including "races". Thus, at that time, a castizo was someone closer to a Spaniard in looks but with some degree of racial mixture; mestizos were those of Spanish and Indian descent, although this group would certainly encompass also those Indians living outside the Indian town councils; and mulatos were those with Spanish and African ancestors. Nonetheless, ethnic classification was not independent from the social position of the person and the context in which he or she would be acting.

8 See both Maddison Historical Statistics and Maddison Project Database 2018. https://www.rug.nl/ggdc/historicaldevelopment/maddison/. Accessed in February 2018.
} 
comparison of numeracy, including a brief examination of the relationship between age heaping and GDP per capita for a number of countries; the last section presents some final remarks.

\section{ESTIMATING AGE HEAPING IN CENTRAL NEW SPAIN: OUR SOURCES AND THEIR}

\section{RELIABILITY}

A unit of measure is needed to estimate and compare age heaping of groups across time and space. The Whipple Index has been used by demographers and other social scientists for many years. To the best of our knowledge, this technique for estimating age heaping was popularized among economic historians by A'Hearn, Baten and Crayen (2006). The also proposed a linear transformation of the Whipple Index, which is known as the ABCC Index. In order to make comparisons with other studies easier, both indices are used in this article. More details about them can be found in Appendix 1.

An illustration of age heaping in our sample is shown in Figure 1. Ages cluster at numbers ending in 5 and, especially, 0 . This tendency is especially visible, in this case, at ages 30, 40, 50 and 60 . Studies of historical age heaping conventionally use the range 23-62 years of age, which is presented in Figure 1. Age heaping is clearly perceptible across Central New Spain in both females and males. The sources of our research are shown in Table 1.

FIGURE 1

Age heaping in Central New Spain (second half of the eighteenth century)
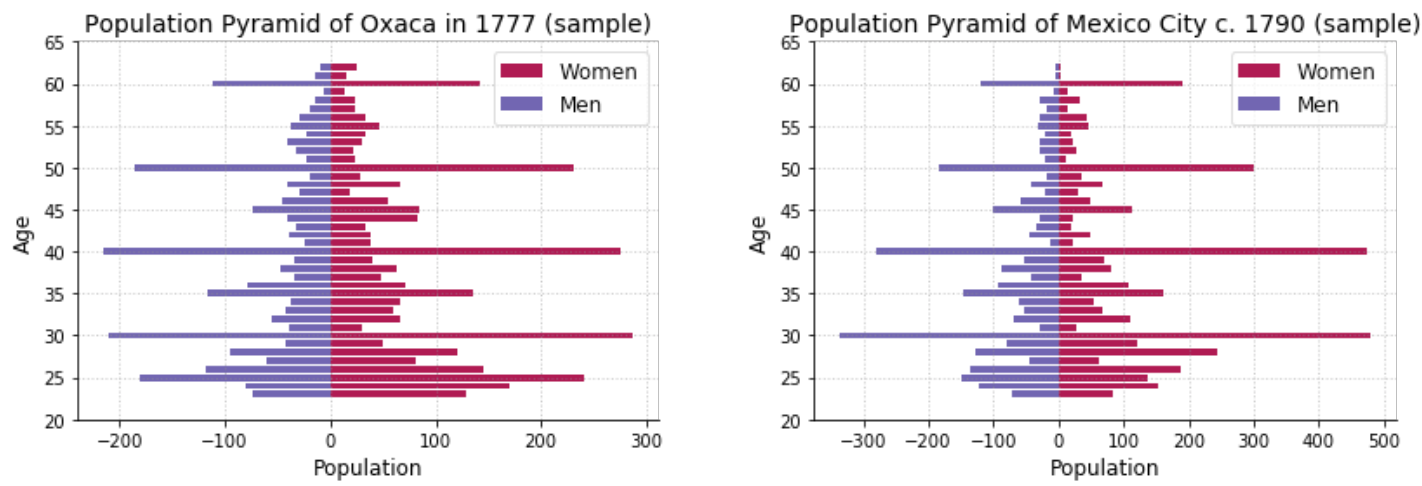


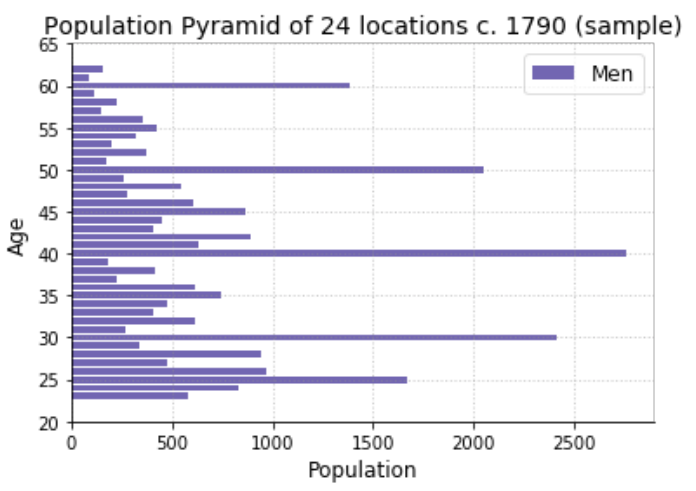

Source: See Table 1.

TABLE 1

Sample and sources. (1)

\begin{tabular}{|l|c|c|c|c|c|l|l|}
\hline & $\mathrm{N}$ & Males & Females & Rural (6) & Ethnicity & Source & Year \\
\hline Oaxaca & 5,631 & 2,452 & 3,179 & 0 & All (2) & Padrón eclesiástico & 1777 \\
\hline City of Mexico & 6,665 & 2,877 & 3,788 & 0 & All (3) & Censo de Revillagigedo & c. 1790 \\
\hline 24 localities (4) & 30,044 & 30,044 & 0 & 16,257 & Various (5) & $\begin{array}{l}\text { Padrones militares del } \\
\text { Censo de Revillagigedo }\end{array}$ & c. 1790 \\
\hline Total & 42,340 & 35,373 & 6,967 & 16,257 & & & \\
\hline
\end{tabular}

Notes:

(1) Age range for the three samples: 23-62

(2) Españoles, indios, mestizos and mulatos and unclassified.

(3) Castizos, españoles de México, españoles peninsulares, indios, mestizos, negros, and calidades no especificadas.

(4) Acámbaro, Atlixco, Celaya, Charo, Chicontepec, Cholula, Dolores, Guanajuato, Huamelula, Huejotzingo, Otumba, Pénjamo, Querétaro, San Cristobal Ecatepec, San Felipe, San Juan del Río, San Miguel el Grande, Silao, Tacuba, Tepeaca, Tlaxcala, Tochimilco, and Tula.

(5) Útiles and exentos (castizos, españoles, mestizos, and mulatos) for military purposes.

(6) Rural: Locations labeled in the Padrones as villages, estates, ranches, glens and other terms suggesting rurality.

All sources report ages. The workable samples appear in the column headed $N$. The original documents also include the population younger/older than 23-62 years of age and/or that does not report sex or ethnicity. Therefore, they have been excluded from our sample. In some cases (e.g., Padrón Eclesiástico de Oaxaca and Censo de Revillagigedo), the information provided includes Indians and females. Both human groups have not been commonly present in the literature on age heaping in the pre- 
industrial era. Quantitative information regarding these groups turns out to be very useful for discussing the extent of capital formation among unprivileged groups of the late viceregal society and quantitatively determining the degree of inequality along the social ladder in this respect. In Table 1 we distinguish between rural and urban populations.

What we consider Central New Spain comprises those areas of the high plateaus that concentrated most of the population of the Viceroyalty, consisting of the intendancies of Guanajuato, Puebla, Mexico, Valladolid, and Oaxaca, and the government of Tlaxcala, all of them represented in our sample -see Map $1 .{ }^{9}$ The land area and the population of this region were, respectively, more than 500,000 kilometers and nearly 4 million people around $1790 .{ }^{10}$ It was not only the most populated region of New Spain, but also the most densely occupied, having a rather high urbanization rate.

MAP 1

Geography of our sample.

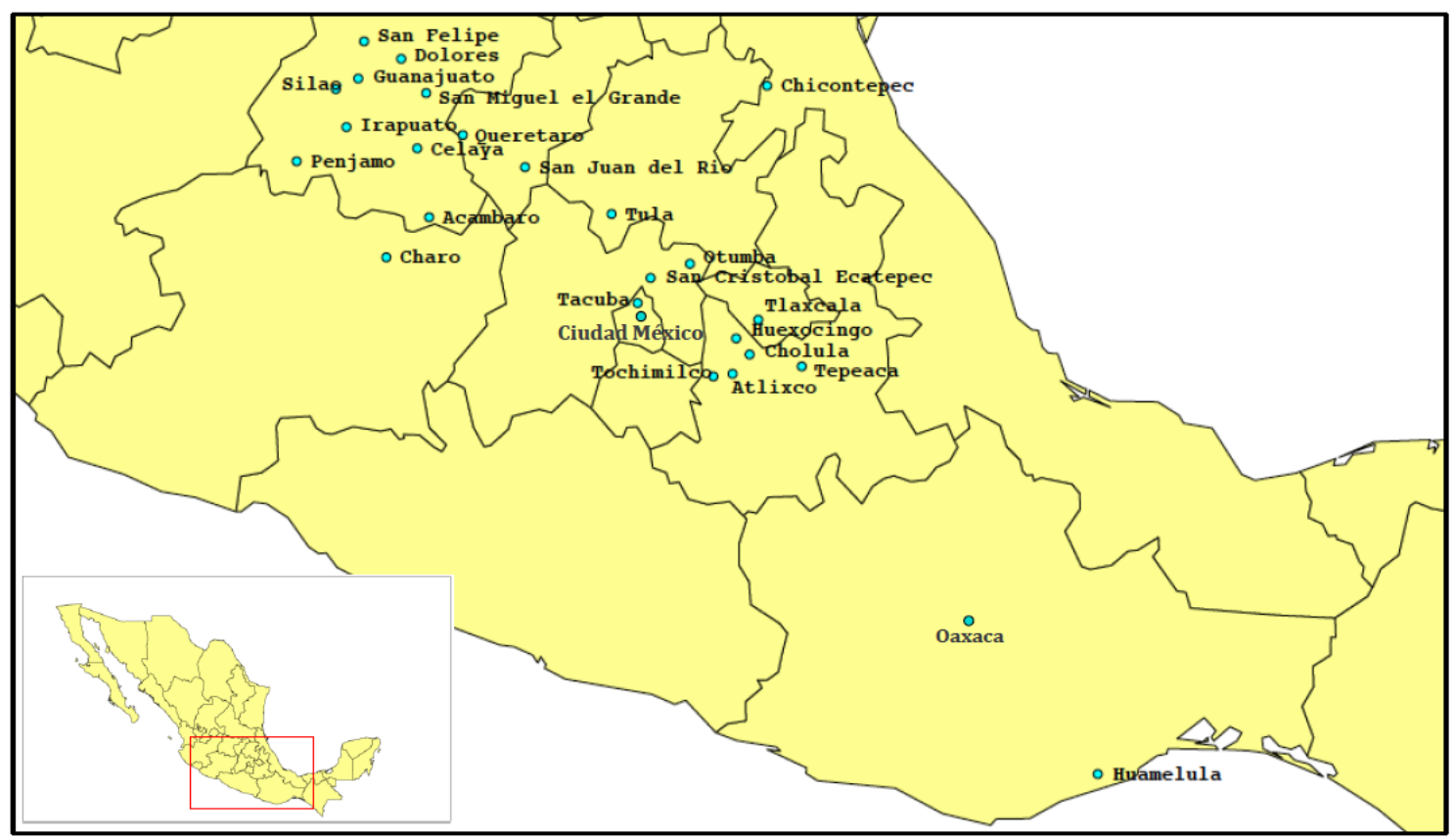

Source: Dobado and García-Hiernaux, (2017). Modern state borders are shown.

\footnotetext{
${ }^{9}$ Only Charo, with 67 individuals in our sample ( 0.3 per cent), belonged to the intendency of Valladolid. Therefore, we have excluded this intendency from our somewhat ad hoc definition of Central New Spain. Map 1 was first used by Dobado and García-Hiernaux (2017). Oaxaca and Mexico City have been added to the original map of the 24 localities included in our sample.

${ }^{10}$ Estimates based on Sánchez Santiró (2007).
} 
In order to determine the reliability of the sources shown in Table 1 some discussion is needed. It is our contention that there are good reasons to be confident in the quality of the sources used as well as in the representativeness of our sample. One reason for this confidence is that all sources presented in Table 1 have been previously used by other researchers in several historical fields. Thus, the Padrón eclesiástico de Oaxaca and the Censo de Revillagigedo were employed, and praised, by Manzel et al. (2012) in their pioneer examination of age heaping in Iberian America from the seventeenth to the twentieth century. ${ }^{11}$ According to these authors, Hispanic America was unique among non-European countries because of the availability of ecclesiastical and official sources (padrones and censos). The trust in the reliability of the sources of the pre-independent period was first pointed out by Cook and Borah (1977-1980); the census was carefully collected following a precise and standardized questionnaire printed in Mexico City and sent to all corners of the kingdom. Sánchez Santiró (2004a, 2004b) based his studies of the population of the City of Mexico and its "new parochial order" on the Padrón del Arzobispo de México (1777). ${ }^{12}$ Pérez Toledo and Klein (2004) also rely, as other authors in Miño-Grijalva (2004), upon the Censo de Revillagigedo in their contribution to this collective book on the population of the City of Mexico in 1790. The military padrones of the Censo de Revillagigedo have been used by Grajales and López (2011) and Dobado and García-Hiernaux (2017) in their studies of heights. Besides, to the best of our knowledge, no well-founded criticism of the quality of the sources used in this work exists. Carlos Marichal $(2007$, p. 56) has acknowledged "the high quality of the Bourbon accounting records of taxes and expenditures from 1760 on." After a long time working with our sources it is difficult not to reach the same conclusion.

Our approach to studying age heaping in late eighteenth-century Central New Spain differs from that of Manzel et al. (2012), since we have opted for an in-depth

\footnotetext{
${ }^{11}$ The Padrón Eclesiástico de Oaxaca was elaborated in response to a Royal Decree issued by King Charles III at El Escorial in 1776. The decree was intended for the whole Empire and should include all individuals. It was conducted by the respective ecclesial authorities, such as the Bishop of Oaxaca in this case. Sánchez Santiró (2004a). The Censo de Revillagigedo was the first modern general census of New Spain.

${ }^{12}$ This padrón also responded to the Royal Decree of 1776.
} 
analysis of our sources, due to the vast array of information that they provide. Therefore, we can only conduct a synchronic analysis (1777 for Oaxaca and c. 1790 for Mexico City and the other 24 localities), although using a much larger sample and a broader set of data (ethnicity, sex, and marital status) than previous studies. Fortunately though, the richness of the censuses offers a strong argument in defense of their reliability: if the data were not self-reported by those being registered, why do we find differences in age heaping between ethnic groups, sexes and other possible segments (i.e., married versus unmarried women) of the whole population in our sample? These differences are significant (see Section III). If the officials in charge makers of the Padrón eclesiástico de Oaxaca and the Censo of Revillagigedo had fabricated the answers, we would find a lower variance between age heaping across subsamples (e.g., between indios and españoles). Moreover, some counterintuitive findings -see Section III- support this argument.

In spite of the consensus among specialists regarding the quality of our sources, some flaws have been observed by Manzel et al. (2012). The most important of them is evident in Table 1: the overrepresentation of females in urban localities. The aforesaid authors suggest that the attempt at avoiding the military draft might be the cause of the underrepresentation of males in Spanish American censuses. Sánchez Santiró (2004a) proposes another explanation for the underrepresentation of single males (slightly more than 60 per cent of single females) in all the parishes of Mexico City in 1777: the immigration of young women to find employment as servants. If there is a bias in our estimates of age heaping due to the overrepresentation of females could introduce in our estimates of age heaping, it would presumably be downwards. Nevertheless, as discussed below, the reality in New Spain might be more complicated than that. In any case, since "Latin America is the only continent in the developing world for which such early population counts are widely available", the temptation to use them carefully is difficult to resist, while the advantages of doing so clearly exceed those of its alternatives. ${ }^{13}$

As to the representativeness of our sample, it is certainly a small share of Central New Spain's total population of nearly 4 million according to the estimates by

\footnotetext{
${ }^{13}$ Manzel et al. (2012, p. 938), quoting Platt, (1998, p. 7).
} 
taken from Sánchez Santiró (2007). It was by far the most populated region of New Spain, either absolutely or in terms of density. Urban life was especially vibrant in this region. Our sample represents around $1.1 \%$ of total population. This percentage increases to 2.1 when we use as denominator the population of 23 to 62 years of age ${ }^{14}$ This new percentage might be viewed as small all the same. However, this is not the case at all. Working with "small samples" is the rule rather than the exception in studies of age heaping for the preindustrial era (e.g., Manzel et al., 2012; Juif and Baten, 2013; Tollnek and Baten, 2017). Recent studies of age heaping for the Spanish case share this peculiarity (Álvarez and Ramos, 2018; Gómez Aznar, 2019). All types of practical obstacles conspire against the attempt to build "large databases" when doing research on the Early Modern Era. ${ }^{15}$ Therefore, our sample is unprecedented in this respect. We are confident in the representativeness of our sample. The representativeness of our sample for studying numeracy in late pre-independent Central Mexico is unusually rich, and not just because of the size, but also due to the inclusion of all significant subsamples in a society for which no specific age heaping estimates had been calculated before (e.g., villagers, indios and castas, single women, etc.). Moreover, the representativeness becomes much more satisfactory in quantitative terms if we substitute Central New Spain for the population aged 23-62 (females and males in Oaxaca and Mexico City; just males in the 24 localities) in the villages, towns and cities included in our sample. In this case, depending on the estimates of Mexico City's population (between 168,000 and 131,000$)^{16}$, the share of our sample rises to $25-29$ per cent -see Table $2 .^{17}$

\footnotetext{
${ }^{14}$ We apply the percentage of people of both sexes aged 23-62 estimated for the City of Mexico (52.2 per cent) to the whole population of Central New Spain. Using that of Oaxaca (50.7 per cent) would not make a change.

${ }^{15}$ Scholars working on the nineteenth and twentieth centuries also face specific, but different, problems. Thus, Beltran et al. (2018) work with samples of millions of observations in their research on age heaping and literacy in Spain between 1877 and 1930 since general censuses of the Spanish population are available for that period.

${ }^{16}$ The higher number of inhabitants has been suggested by one of the referees while the source of the lower one is Calderón (2016).

17 In the cases of Oaxaca and the 24 localities, the main and practically only reason for explaining the differences between our sample of people aged 23-62 and the total population in the same segment of years is that some registers do not include information about any of the relevant characteristics of the individuals (i.e., age, ethnic condition, sex and marital status) to our research.
} 
TABLE 2

Representativeness of our sample

\begin{tabular}{|c|c|c|c|c|}
\hline & & & Population & \\
\hline & & $\begin{array}{c}\text { Sample } \\
(\text { I) }\end{array}$ & $\begin{array}{c}(23-62) \\
(I I)\end{array}$ & $\begin{array}{c}\text { I/II } \\
(\%)\end{array}$ \\
\hline Oaxaca & & 5,631 & 9,124 & 61.7 \\
\hline City of Mexico (1) & 6,665 & $87,696 / 68,382$ & $7.6 / 9.7$ \\
\hline 24 localities (2) & 30,044 & 46,642 & 64.4 \\
\hline Total & 42,340 & $143,462 / 124,148$ & $29.5 / 34.1$ \\
\hline \multicolumn{4}{|l}{} \\
\hline (1) See explanations in text. & & & \\
\hline (2) Estimated with City of Mexico ratios. Only males. See text. \\
\hline
\end{tabular}

Source: See Table 1.

As shown in Table 2, the representativeness of our sample is unusually large with respect to Oaxaca and the 24 localities (respectively, almost two-thirds of both females and males and more than half of the male population aged 23-62 and somewhat less so in the case of the City of Mexico). However, as argued below, its relatively small size does not affect its representativeness -see Map 2.

\section{MAP 2}

Mexico City in 1790, divided in 32 cuarteles menores 


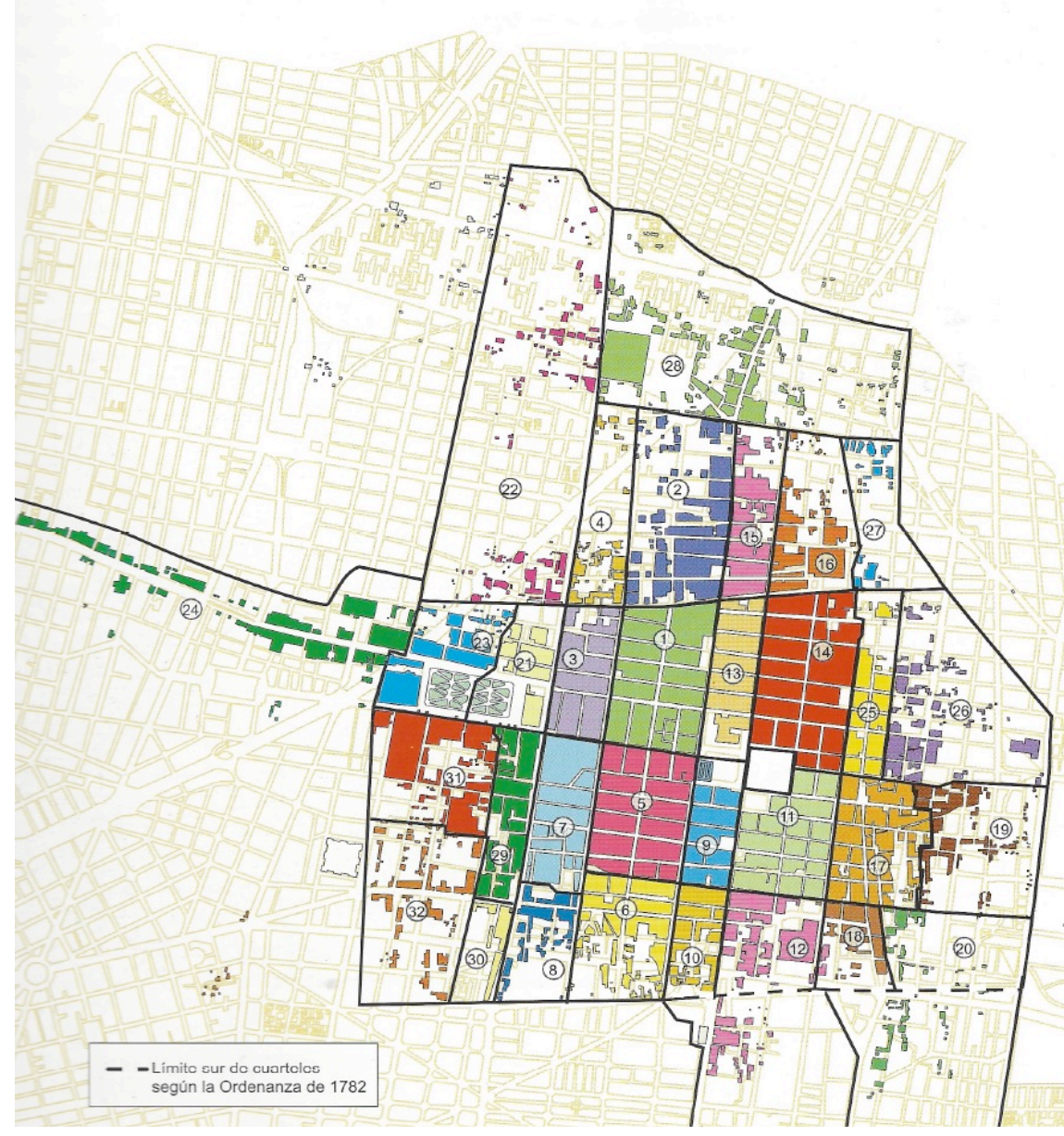

Source: Lombardo et al. (2009)

Our subsample for the City of Mexico consists of the whole population of three cuarteles menores (1, 20, and 23). Pérez Toledo and Klein (2004) clearly explain why this selection of cuarteles menores is a good representation of Mexico City as a whole: the first cuartel menor (olive green) comprises the very core of the city, while the other two (20, bottom right in green, and 23 , center left in blue) represent the outskirts, which covered well areas of the repúblicas de indios of Santiago Tlatelolco and San Juan Tenochtitlán -see Map 2. Thus, while the 1st cuartel menor occupied a central location and was relatively rich, although not without a significant number of commoners among its inhabitants, the 20th and 23th cuarteles menores were peripheral and comparatively poor. The share of españoles and negros was above the average in the relatively rich cuartel menor 1 . The opposite happened in the other two, poorer, areas. Indios were found in similar proportions in all three areas. 


\section{AGE HEAPING IN CENTRAL NEW SPAIN IN THE SECOND HALF OF THE EIGHTEENTH}

CENTURY.

In this section we show our estimates of age heaping measured with the Whipple and ABCC indexes -see Appendix 1.

TABLE 3

Age heaping in late eighteenth-century New Spain.

\begin{tabular}{|l|c|c|c|c|c|c|c|c|c|}
\hline & \multicolumn{3}{|c|}{ Oaxaca } & \multicolumn{3}{c|}{ Mexico City } & \multicolumn{3}{c|}{ 24 localities } \\
\hline & $\mathrm{N}$ & Whipple & ABCC & $\mathrm{N}$ & Whipple & ABCC & $\mathrm{N}$ & Whipple & ABCC \\
\hline Females & 3,179 & 226.5 & 68.4 & 2,877 & 233.7 & 62.3 & 0 & - & - \\
\hline Males & 2,452 & 230.6 & 67.3 & 3,788 & 250.8 & 66.6 & 30,044 & 245.1 & 63.7 \\
\hline Urban & 5,631 & 228.3 & 67.9 & 6,665 & 243.4 & 64.1 & 13,787 & 265.0 & 58.8 \\
\hline Rural & 0 & - & - & - & - & - & 16,257 & 228.9 & 67.8 \\
\hline Total & 5,631 & 228.3 & 67.9 & 6,665 & 243.4 & 64.1 & 30,044 & 245.1 & 63.7 \\
\hline
\end{tabular}

Source: See Table 1.

As expected, numeracy -proxied by age heaping- in Central New Spain was certainly not high, but it was not so low either when compared with historical or even contemporary populations. Central New Spain lagged behind Scandinavia and Western Europe. However, it was not far from Italy and Portugal and exceeded Ireland c. 1800 and most of Eastern Europe by 1820 (Hippe and Baten, 2011). ${ }^{18}$ Moreover, age heaping was also significantly lower than in the Cape Colony, in particular if only the non-European part of the sample is taken into account (Baten and Fourie, 2015). Besides, it was lower than in most of the rest of the underdeveloped world as late as 1900 and even later (Crayen y Baten, 2010a; Hippe, 2012). However, China and East Asia were more numerate than Central New Spain (Baten et al. 2010; Baten and Sohn, 2017). Thus, we share the conclusion expressed by Manzel et al. (2012, p. 958): "It is safe to say that until the late eighteenth century numeracy levels in Latin American countries were quite good."

Values of the Whipple and $A B C C$ indexes in the three subsamples are basically similar. We can probably assume that age heaping in the 24 localities would be lower if

${ }^{18}$ Other estimates for Ireland offer a higher ABCC index: 77 ( $A^{\prime}$ Hearn, 2006) and 85 (Tollnek and Baten, 2017). 
indios and females were included in that subsample. We advance that this presumption might be accurate as far as indios are concerned. On the contrary, it is not necessarily so regarding females, given the estimates for Oaxaca -see Table 3where female numeracy is slightly higher than that of men. Finding that females are more numerate than males is not an exceptional result -see Table 4- but it is not the most common one either.

TABLE 4

Ratio males over females heaping, late Medieval and Early Modern periods

\begin{tabular}{|l|c|c|l|c|c|c|}
\hline \multicolumn{7}{|c|}{ Males/females $^{*}$} \\
\hline & Years & Whipple & & Years & Whipple & ABCC \\
\hline Tuscany & 1427 & 0.92 & Antwerp & 1796 & 1.09 & \\
\hline Tuscany & 1427 & 0.89 & Flemish Brabant & 1796 & 1.11 & \\
\hline Florence & 1427 & 0.70 & Amsterdam & $1730-1799$ & 0.97 & \\
\hline Brugge & $1474-1524$ & 0.95 & Oaxaca & 1777 & 1.02 & 0.98 \\
\hline Norwich & 1570 & 1.05 & Mexico City & c. 1790 & 0.93 & 1.08 \\
\hline England and Wales & 1851 & 0.99 & Olot & 1716 & & 0.95 \\
\hline Italy & 1871 & 0.91 & Badalona & 1716 & & 1.05 \\
\hline \multicolumn{7}{|l|}{} \\
\hline $\begin{array}{l}\text { *If the quotient is higher than 1 in the Whipple column, the numeracy of women exceeds that of } \\
\text { males. The opposite happens when we look at the column showing the ABCC males/females ratio. }\end{array}$ \\
\hline
\end{tabular}

Source: Padrón eclesiástico de Oaxaca, Censo de Revillagigedo, Földváry et al. (2012), Gómez Aznar (2019), A’Hearn (2017) and De Moor (s.d.).

While in New Spain age heaping among females was high if compared with Western Europe in the Late Medieval and Early Modern times, the gap between males and females is similar. These results are probably unexpected. This dimension of inequality in New Spain was not more acute than in other allegedly less patriarchal societies. We also try to test whether the objection raised by Földvári et al. (2012, p. 312 ) to the conventional estimates of age heaping among women (i.e. all female individuals aged 23-62) makes sense in our case. For these authors, "to calculate actual age heaping among women reliably, it is preferable to use data on non-married women." Therefore, we have also calculated the Whipple and ABCC indexes of the female population of Oaxaca -the only subsample for which it is possible- for the three marital-status categories -see Table 5. 
TABLE 5

Female age heaping in Oaxaca, 1777

\begin{tabular}{|c|c|c|c|c|c|c|c|c|c|}
\hline & \multicolumn{3}{|c|}{ Single } & \multicolumn{3}{|c|}{ Married } & \multicolumn{3}{|c|}{ Widowed } \\
\hline Ages & $\mathrm{N}$ & Whipple & $A B C C$ & $\mathrm{~N}$ & Whipple & $A B C C$ & $\mathrm{~N}$ & Whipple & $A B C C$ \\
\hline $23-32$ & 562 & 191 & 77 & 649 & 199 & 75 & 100 & 245 & 64 \\
\hline $33-42$ & 262 & 231 & 67 & 447 & 246 & 63 & 127 & 276 & 56 \\
\hline $43-52$ & 191 & 217 & 71 & 247 & 219 & 70 & 204 & 304 & 49 \\
\hline $53-62$ & 127 & 256 & 61 & 90 & 183 & 79 & 168 & 281 & 56 \\
\hline Total* & 1,142 & 212 & 72 & 1,433 & 216 & 71 & 599 & 282 & 55 \\
\hline
\end{tabular}

Source: Padrón eclesiástico de Oaxaca.

Our estimates show that widows heap ages more than married women in all ranges of ages. This evidence supports the claim of Fölvári et al. (2012) that the numeracy of married women is overestimated because married women adjust their age to that of their husbands. By doing so, they reduce their age heaping and, consequently, that of the whole female population in the sample. However, single women heap ages less than married women, which is evidence against the alternative proposed by Fölváry et al. (2012). In sum, we find mixed evidence regarding the objection raised by these authors. Two issues arise here. First, since widows tend to be older, it is possible that they had more difficulties remembering their precise age. Second, it is also possible that numeracy had progressed during the 18th century in Oaxaca and that younger, unmarried women were better educated than older generations.

Our results regarding females might have another and more complex explanation. On the one hand, in the cities and major towns, feminine convents played a major role in the education of women. Nuns taught the Catholic faith, as well as reading, writing and various crafts to young girls. Since nunneries were plentiful -even in small towns like Villa de Carrión (nowadays Atlixco) in the Puebla region or Salamanca in Guanajuato-, and hundreds of girls spent at least a couple of years within the convent walls, the fact that we find relatively high numeracy rates among women in both Mexico City and Oaxaca, especially among those of Spanish descent (Table 6), does not seem surprising. In the $18^{\text {th }}$ century, because of the enlightened ideas which promoted the improvement of the instruction of all human beings, female 
education received even more attention in New Spain. The most important institution for women opened in that century was the Colegio de San Ignacio de Loyola de los Señores Vizcaínos in Mexico City. It started its operations in 1767 and had 260 intern colegialas by $1795 .{ }^{19}$ In 1793 , in the same, impressive building -it covers an area of more than 17,000 square meters-, a public school for girls not residing in the Colegio opened its doors, and soon afterwards it was serving almost 500 students. The teachers of this school were chosen among the best intern colegialas. According to Tanck (1999), Indian girls were not excluded from the increase in the number of schools during the second half of the eighteenth century.

The Padrón eclesiástico de Oaxaca reports a high number of nuns among the population. Four nunneries housed 146 nuns along with 15 novices. ${ }^{20}$ The presence of this well-educated -at least relatively- female population and its influence on other women contribute to explain the comparatively low age heaping of single women in Oaxaca. Something similar probably happened in Mexico City and other locations. ${ }^{21}$ Additionally, the overrepresentation of women in petty commerce -an activity for which some arithmetic skills are needed-in urban and rural markets ought to be taken into account. The iconography of the period reflects the presence of women in the open-air commercial space and the studies available also point in this direction (Arrom, 1988). The improvement in the education of women in Spanish America since the third decade of the eighteenth century is also acknowledged by Lavrin (1984). It was part of a wider "educational growth" (Newland, 1991).

Estimates shown in Table 3 depict an image of a certain heterogeneity either between sexes or across space in New Spain. Our micro-approach allows us to delve more deeply into the analysis of the rich dataset extracted from the original sources used. By doing so, new perspectives emerge: spatial heterogeneity and ethnic inequalities. Significant differences in age heaping are observed within the subsample

\footnotetext{
${ }^{19}$ This is one of the few viceregal institutions that still functions nowadays in Mexico.

${ }^{20}$ Fifteen females, aged from fifteen to thirty-eight, appear as belonging to the Colegio del Convento del Rosario. They are listed just behind the four friars of the Convento. Previously, fifty nuns of this convent had been enumerated.

${ }^{21}$ Female religious institutions were increasingly opened to Indians. Some instances are offered by Tanck (1999, p. 425): in 1782, the convent of Our Lady of the Angels, intended for noble Indians, was established in Oaxaca; in 1806, a convent for macehuales (commoners) Indian women was adjoined to the existing Colegio de Indias in the City of Mexico.
} 
constituted by the 24 localities -Table 6 . Finding a high geographical heterogeneity in Central New Spain is not new. Heights also present a significant variability (Dobado and García-Hiernaux, 2017). Thus, while some localities exhibit less age heaping than Oaxaca and Mexico City, in others the opposite happens. Curiously enough, relatively high and low levels of numeracy might coexist at a short distance from each other (e.g., Atlixco and Tochimilco or Dolores and Silao). ${ }^{22}$ Conversely, clustering of both high age heaping (e.g., Dolores and San Felipe) and low age heaping (e.g., Querétaro and Celaya) may be observed.

TABLE 6

Differences in age heaping c. 1790

\begin{tabular}{|l|c|c|c|l|c|c|c|}
\hline & N & Whipple & ABCC & & N & Whipple & ABCC \\
\hline Tula & 592 & 179.1 & 80.2 & San Cristóbal Ecatepec & 219 & 235.2 & 66.2 \\
\hline Dolores & 721 & 187.9 & 78.2 & Penjamo & 788 & 235.4 & 66.2 \\
\hline San Felipe & 744 & 196.2 & 75.9 & Silao & 1,212 & 239.3 & 65.2 \\
\hline San Miguel el Grande & 701 & 201.9 & 74.5 & Huamelula & 111 & 243.2 & 64.2 \\
\hline Huexocingo & 933 & 202.6 & 74.4 & Guanajuato & 4,072 & 248.4 & 62.9 \\
\hline Tacuba & 836 & 205.7 & 73.6 & Charo & 44 & 250.0 & 62.5 \\
\hline Tlaxcala & 2,218 & 211.9 & 72.0 & San Juan del Río & 1,472 & 252.4 & 61.9 \\
\hline Tepeaca & 2,514 & 213.2 & 71.7 & Acámbaro & 687 & 253.3 & 61.7 \\
\hline Atlixco & 1,213 & 216.0 & 71.0 & Chicontepec & 111 & 270.3 & 57.4 \\
\hline Irapuato & 880 & 218.2 & 70.5 & Querétaro & 6,136 & 296.6 & 50.9 \\
\hline Otumba & 262 & 230.9 & 67.3 & Celaya & 2,850 & 282.5 & 54.4 \\
\hline Cholula & 545 & 233.9 & 66.5 & Tochimilco & 143 & 283.2 & 54.2 \\
\hline
\end{tabular}

Source: Padrones militares del Censo de Revillagigedo, AGN, Mexico City.

This diversity in terms of numeracy was probably due to a variable combination of factors operating at the local (promotion of schooling by the elites) and supra-local (regional or sub-regional resource endowment, institutional framework, market integration and economic specialization) scale. What seems clear to us is: 1) microapproaches to the economic history of pre-independent Hispanic America offer interesting new perspectives; 2) empirically unsupported generalizations tend to be

\footnotetext{
${ }^{22}$ The distance between Atlixco and Tochimilco is nowadays $18.1 \mathrm{~km}$. Both Dolores and Silao belonged to El Bajío, the most economically developed area of New Spain.
} 
more and more unjustified with respect to relevant aspects -see below. ${ }^{23}$ Further evidence in favor of a "low-profile methodology" will be presented soon.

One such generalization, as successful in the literature as empirically flawed, emphasizes the "original $\sin$ " of inequality in pre-independent Hispanic America. Numeracy offers the opportunity to test the hypothesis that New Spain was an extreme case of inequality. In order to do so, we use a two-step procedure. First, we present information on age heaping for all ethnic groups in our subsamples -see Table 7 and Figure 2- including females and males for Oaxaca and Mexico City. Second, we estimate some comparative indicators of inequality in terms of numeracy -see Table 8.

\footnotetext{
${ }^{23}$ A growing scholarship is showing that generalizations of this type should be reconsidered as far as some important aspects (i.e., real wages and biological welfare) of pre-independent Hispanic America. Dobado, (2010, 2015); Arroyo et al., (2012); Calderón and Dobado,( 2012); Dobado and Marrero, (2014); Dobado and García-Montero, (2014, 2015); Djenderedjian and Martirén, (2015); Arroyo and Van Zanden, (2016); Dobado and García-Hiernaux, (2017); Llorca et al., (2018), Moraes and Thul, (2018).
} 
TABLE 7

Age heaping by ethnic groups

Panel 1: Oaxaca, 1777.

\begin{tabular}{|c|c|c|c|c|c|c|c|c|c|c|c|c|c|c|c|}
\hline & \multicolumn{3}{|c|}{ Indians } & \multicolumn{3}{|c|}{ Mestizos } & \multicolumn{3}{|c|}{ Mulatos } & \multicolumn{3}{|c|}{ Spaniards } & \multicolumn{3}{|c|}{ Unclassified } \\
\hline & $\mathrm{N}$ & $W$ & $\mathrm{ABCC}$ & $\mathrm{N}$ & W & $\mathrm{ABCC}$ & $\mathrm{N}$ & $W$ & $\mathrm{ABCC}$ & $\mathrm{N}$ & W & $A B C C$ & $\mathrm{~N}$ & W & $\mathrm{ABCC}$ \\
\hline Females & 617 & 292.5 & 52 & 434 & 265.0 & 58.8 & 348 & 275.9 & 56 & 1,086 & 205.3 & 74.6 & 694 & 152.1 & 87.0 \\
\hline Males & 569 & 311.0 & 47 & 287 & 261.5 & 59.6 & 236 & 290.0 & 52 & 658 & 230.2 & 67.7 & 706 & 133.8 & 91.5 \\
\hline Total & 1,186 & 301.6 & 50 & 717 & 263.6 & 59.1 & 584 & 281.7 & 55 & 1,744 & 214.7 & 71.6 & 1,340 & 142.9 & 89.3 \\
\hline
\end{tabular}

Source: Padrones militares del Censo de Revillagigedo.

Panel 2: Mexico City c. 1790.

\begin{tabular}{|c|c|c|c|c|c|c|c|c|c|c|c|c|c|c|c|c|c|c|c|c|c|}
\hline & \multicolumn{3}{|c|}{ Blacks } & \multicolumn{3}{|c|}{ Castizos } & \multicolumn{3}{|c|}{ Indians } & \multicolumn{3}{|c|}{ Mestizos } & \multicolumn{3}{|c|}{$\begin{array}{c}\begin{array}{c}\text { Spaniards from } \\
\text { Mexico }\end{array} \\
\end{array}$} & \multicolumn{3}{|c|}{$\begin{array}{c}\text { Spaniards from the } \\
\text { Peninsula }\end{array}$} & \multicolumn{3}{|c|}{ Unclassified } \\
\hline & $\mathrm{N}$ & W & $\mathrm{ABCC}$ & $\mathrm{N}$ & W & $\mathrm{ABCC}$ & $\mathrm{N}$ & W & $\mathrm{ABCC}$ & $\mathrm{N}$ & W & $\mathrm{ABCC}$ & $\mathrm{N}$ & W & $A B C C$ & $\mathrm{~N}$ & W & $\mathrm{ABCC}$ & $\mathrm{N}$ & W & $\mathrm{ABCC}$ \\
\hline Females & 234 & 331.2 & 42 & 154 & 279.2 & 55 & 581 & 286.6 & 53 & 446 & 263.4 & 59 & 1,827 & 239.7 & 65 & 68 & 250.0 & 63 & 426 & 189.3 & 77.7 \\
\hline Males & 134 & 235.0 & 66 & 114 & 210.5 & 72 & 393 & 283.7 & 54 & 245 & 265.3 & 59 & 1,289 & 236.6 & 66 & 276 & 211.9 & 72 & 478 & 180.7 & 79.8 \\
\hline Total & 368 & 301.3 & 50 & 268 & 250.0 & 63 & 974 & 285.4 & 54 & 691 & 264.1 & 59 & 3,116 & 238.4 & 65 & 344 & 219.5 & 70 & 904 & 185.3 & 78.7 \\
\hline
\end{tabular}

Source: Censo de Revillagigedo.

Panel 3: 24 localities, c. 1790.

\begin{tabular}{|l|c|c|c|}
\hline & Number & Whipple & ABCC \\
\hline Castizos & 2,279 & 231.5 & 67.1 \\
\hline Mestizos & 8,911 & 245.6 & 63.6 \\
\hline Mulatos & 3,110 & 305.0 & 48.8 \\
\hline Spaniards & 15,272 & 234.6 & 66.3 \\
\hline Unclassified & 472 & 210.5 & 72.4 \\
\hline Total & 30,044 & 245.1 & 63.7 \\
\hline
\end{tabular}

Source: Padrones militares del Censo de Revillagigedo. 
FIGURE 2

Age heaping and ethnicity in the whole sample.

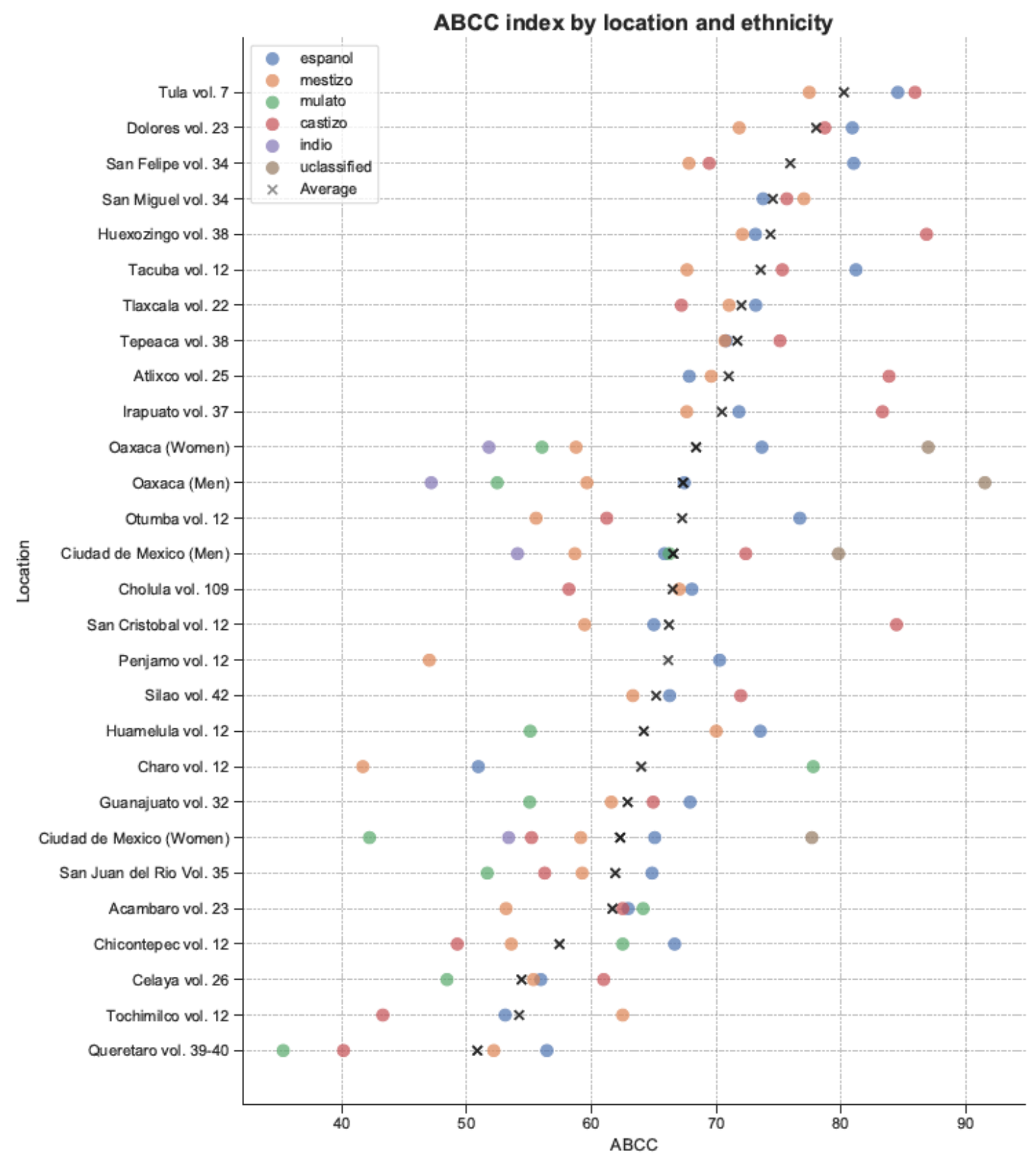

Source: See Table 1.

As expected, the ethnic division permeated nearly all aspects of life in New Spain, numeracy not being an exception. In Oaxaca, only Spaniards, both males and, especially, females, heaped less than the average, whereas the opposite happens to the rest of ethnic groups. Female age heaping of all groups, except mestizos, is lower than that of males. The estimates for negros in Mexico show an unusual gap between men and women, mainly because of the especially low numeracy of the latter. 
Spaniards from the Peninsula, men in particular, heaped less than the other ethnic groups, Spaniards of Mexico included. Overall, estimates for Oaxaca seem basically consistent with those from Mexico City and the 24 localities. Somewhat surprising is the fact that in the latter subsample age heaping is higher in urban locations than in the rural ones -see Table 3-, although this finding is consistent with the idea of heterogeneity based on geography and with the importance of local factors (i.e., the existence or not of a "municipal education policy") at explaining the level of numeracy of the inhabitants.

Available estimates for all ethnic groups in our three subsamples (Oaxaca, Mexico City and the 24 localities) are plotted together in Figure 2. It offers an interesting new perspective on ethnic inequality and spatial diversity in Central New Spain. The ABCC indexes of the non-specified ethnic groups are presented. They add complexity to the diverse panorama of numeracy. In some locations, several ethnic groups (unclassified men and, in particular, women from Oaxaca, along with, more generally, españoles and castizos) reach $A B C C$ values comparable to those of the European periphery; that is, a high level for the world standard of the period. These two groups are usually at the top of the ranking and above the rest of ethnic groups. Mulatos and indios from Oaxaca and Mexico City are at the bottom. Thus, the ethnic division is clearly visible. However, the role played by ethnicity was influenced by local and supra-local factors; indios from Oaxaca and Mexico City do not have lower levels of numeracy than other ethnic groups from the localities placed in the bottom part of Figure 2, including in some cases españoles (e.g., Charo and Tochimilco). It is likely that indios from the localities situated in the upper part of Figure 2, for whom we do not have information, would also be in a similar or better situation than those from Oaxaca and Mexico City. This inference is based on the additional information provided by Tanck (2011). ${ }^{24}$ Besides the incentive represented by an easier access to becoming part of the clergy, there might have been more mundane ambitions as well (e.g., an active participation in the expanding market economy). It is quite interesting to observe that, as a general rule -i.e., excluding ethnically unclassified individuals-, there is a tendency

24 "During the eighteenth century the interest of 'indios' in education increased since in 1697 it was declared that 'they can be ordered in sacris, admitted in schools, seminars and religions and promoted to dignities and public offices, ending the prohibition imposed in the sixteenth century." Tanck, (2011, p. 81). Our translation. 
to present higher dispersion in localities in which the average age heaping is also higher.

Demand factors for education were reinforced by supply factors. According to Tanck (1999), Visitor General José de Gálvez established in 1766 the Contaduría General de Propios, Arbitrios y Bienes de Comunidad (General Accounting Office of Customs, Excise and Community Assets), which limited the autonomy of the municipalities and supervised how money was spent. More than 1,600 towns in New Spain adopted the new system between 1773 and 1785. The intention was to avoid municipalities' indebtedness that could compete with the Crown in the search for loans within the Viceroyalty. Besides, it would generate surpluses that could be used by the Crown when needed, basically to finance the costly wars against Britain. In the Repúblicas de indios expenses for religious activities were severely limited, but certain outlays were permitted or even encouraged. This was the case of public schools. After contemplating the sequestration of the surplus resources that they had saved during the war against the British (1778-1783), most Indian councils decided to spend nearly all available resources on "useful works" within their jurisdiction, among which schools were the most favored. For instance, in Mexico City, free public schools were established in the Indian areas before the city council opened a school in 1786. In $1803,1,104$ schools were operating in 4,271 pueblos de indios. They were entirely financed by the cajas de comunidad. Thus, $26 \%$ of the Repúblicas de indios of New Spain had a school of elementary education. This percentage rises to 43 and 32 per cent in the intendencies of, respectively, Mexico and Michoacán and to nearly $50 \%$ in Guanajuato (Tanck, 1999, p. 286).

Numeracy among New Spain indios may be considered low, if only by the standards of the most advanced parts of the world. In any case, the fact is that numeracy, not to mention literacy, in pre-Hispanic America seems to have been much lower. Following Juif and Baten (2013, p. 241), the long-term negative impact of "precolonial legacies" ought not to be underestimated and not only as far as numeracy and human capital accumulation are considered:

"Given the low educational level and the high inequality reigning before the Spanish conquest in the Andean region, we argue that more attention should be 
paid to the pre-colonial legacies when assessing the genesis of the long-term path of only modest economic growth in the countries of Latin America."

As recognized by Engerman and Sokoloff (2002) themselves, the "preexisting Native American organizations in those areas" [Mexico and Peru] "significantly influenced Spanish practices" that led to extreme inequality. We believe that the preHispanic institutional legacy was certainly important, but not exactly in the way thought by Engerman and Sokoloff. Thus, according to Coatsworth (2005, p. 139):

"Unlike Western Europe, Latin America's colonial elites did not monopolize land ownership. Throughout Mesoamerica and the Andes, indigenous villages and villagers occupied most of the arable lands. European estates clustered in the commercially more profitable areas near cities and towns and along major trade routes but left vast areas of the landscape in indigenous hands."

There is no good reason to believe that pre-Hispanic New Spain was any different from the Andean region regarding the scarce education of commoners. There is abundant evidence of progress in this domain throughout the Early Modern Era in New Spain. Shortly after the Conquest of Tenochtitlan (1521), the authorities of the new Viceroyalty encouraged the establishment of educational facilities for both the small but growing Spanish population, as well as for the large Indian groups. This was not a gracious concession but a legal requirement; the Pope's cession of American lands to the Crown of Castile demanded the incorporation of Indians to Christianity. The Colegio Imperial de la Santa Cruz de Tlatelolco, founded in 1536, is the best-known and most important educational institution dedicated to the instruction of the Indian elite. In 1539, a printing press was introduced in Mexico City to help the friars teach the new faith to the Indians. By 1553, the Royal and Pontifical University of Mexico opened its first courses. Therefore, we do sense that the statement that "with the slightest research on the life of New Spain, the very liberal and $19^{\text {th }}$ century prejudice that during colonial times public education was neglected, shatters and falls to earth" is basically correct (Gonzalbo, 2000, p. 14. Our translation).

Although in the cities and among the Spanish population education continued to progress in the seventeenth century -for instance, the Jesuits, established in New Spain in 1572 and opened dozens of schools-, among the Indians the initial thrust was lost and in the aforesaid century education seems to have made little progress. In the 1680s the energetic Archbishop of Mexico, Francisco de Aguiar y Seixas, visited most of 
his jurisdiction and found that although there were no traces of paganism among the Indians, their knowledge of Christian doctrine was rather sketchy due to their superficial knowledge of Spanish. Aguiar obtained from the Crown a series of royal charters that demanded the establishment of schools in parishes that should basically teach Spanish and religion. These regulations led to the creation of dozens of schools and many of them also taught how to read and write. Many towns remained nevertheless without schools. This would explain why Viceroy Marques of Valero insisted on applying the royal decrees in the $1710 \mathrm{~s}$.

When the enlightened Manuel José de Rubio y Salinas assumed the archiepiscopal throne of Mexico, he commissioned a census of the existing schools in the territory of his see. The reports he received informed of the existence of 287 schools in 281 localities in 1754 (Tanck, 1999). Rubio y Salinas encouraged the opening of more facilities; this policy was also pursued by his successor, Francisco Antonio de Lorenzana, and extended to the other bishoprics by the regalist bishops appointed by Charles III - such as Francisco Fabián y Fuero in Puebla.

The promotion of education was not only left to the Church during the reign of Charles III. Private education also played a role of some importance in New Spain. In 1779, there were 30 paying schools for boys and 91 for girls in Mexico City (Tanck, 1998, p. 161). Some teachers were teaching more than a hundred pupils, but the majority taught between 15 and 25. After the decree of Viceroy Gálvez, dating from 1786, which obliged convents and parishes to open free elementary schools, new educational facilities flourished, diminishing thus the demand for private teachers.

The extension of education during the eighteenth century paid off in New Spain. The extension of literacy allowed the diffusion of the technical advances of the Enlightenment. For example, several priests enrolled in the Real Sociedad Bascongada de Amigos del País -an enlightened network of Basque origin with subscribers in four continents- ordered hundreds of copies of the agricultural manuals written by the members of the society to distribute them in the Indian communities in which they preached, sometimes at the request of the local caciques (Torales, 2001). This shows a population able to readcapable of reading and also to take advantage of the enlightened advances. Undoubtedly, this formation of human capital is part of the explanation of the general prosperity of the viceroyalty at the end of the $18^{\text {th }}$ century. 
Thus, abundant evidence suggests that the Enlightenment was not alien to New Spain's education history. However, its outcomes were neither spectacular nor equally distributed. Some regions (Central New Spain) did better than others (Peripheral New Spain) but this was common elsewhere. No minor regional differences in numeracy may be observed in European countries (e.g., Austria-Hungary, France, Italy, Norway, Spain, and the United Kingdom) around the early nineteenth century (Hippe and Baten, 2011). Inequalities between ethnic groups existed and were significant. Therefore, since the distinction between ethnicity and socioeconomic status was not so clear-cut, the international comparison of inequality in numeracy shown in Table 7 is revealing.

The tentative indicators depicted above allow us to conclude tentatively, that New Spain was not an extremely unequal society in terms of numeracy ${ }^{25}$. The estimated ratios for New Spain are not very different from those available for advanced countries. ${ }^{26}$ In contrast, the inequality in Cape Colony was of a different order of magnitude.

TABLE 8

Inequality in numeracy

\begin{tabular}{|c|c|c|c|c|}
\hline & & Whipple & $A B C C$ & \\
\hline France & $1650-1769$ & 0.9 & - & Taller/shorter halves, army \\
\hline Paris & $1650-1769$ & 0.7 & - & Idem \\
\hline Southern Netherlands & 1796 & 0.9 & - & Professionals/Unskilled labourers, men \\
\hline USA (north) & 1800-1839 & 1.0 & - & $\begin{array}{l}\text { Upper/lower parts of the occupational } \\
\text { hierarchy, men }\end{array}$ \\
\hline Idem & $1840-1879$ & 0.9 & - & Idem \\
\hline USA (south) & $1800-1839$ & 0.8 & - & Idem \\
\hline Idem & $1840-1879$ & 0.8 & & Idem \\
\hline Cape Colony & $1692-1827$ & & 3.3 & Europeans/non-Europeans (theft prisoners) \\
\hline Idem & $1692-1827$ & & 3.0 & Idem (murder prisoners) \\
\hline Oaxaca & 1777 & 0.7 & 1.5 & Spaniards/Indian (Whipple), men \\
\hline Mexico City & c. 1790 & 0.7 & 1.4 & Castizos/Indians, men \\
\hline 24 localities in New Spain & c. 1790 & 0.8 & 1.3 & Castizos/Mulatos, men \\
\hline
\end{tabular}

Source: Crayen and Baten (2010), Baten and Fourie (2015), Padrón eclesiástico de

Oaxaca, Censo de Revillagigedo and Padrones militares del Censo de Revillagigedo.

${ }^{25}$ The closer to a value of 1 the ratios are, both for Whipple and ABCC indexes, the more egalitarian in terms of numeracy the society is.

${ }^{26}$ By construction, some of the ratios might underestimate inequality: division of halves in France and Paris; exclusion of black slaves in the Southern United States. 
In view of this evidence, together with that presented above, we do not think that New Spain was a case of extreme inequality in terms of numeracy and hence human capital formation as Engerman and Sokoloff (2005) maintained. It rather confirms the conclusion that much more empirical evidence is needed to support the view of viceregal Spanish America as the epitome of extreme inequality (Dobado, 2009; Dobado and García-Montero, 2010). In this regard, neither Coatsworth (2005, 2008) nor Williamson (2009) shares that pessimistic view. In fact, at least in urban environments, ethnic educational discrimination was not as strong as usually assumed:

"In cities like Puebla or Mexico, and probably in the rest of the urban centers, most students attended public schools, financed by either the councils, philantropical groups, the Church, or the Indian towns. Children of all ethnic and economic groups coexisted in the same classroom, without legislation or customs that could prevent this practice." (Tanck, 2011, p. 91. Our translation).

This view, at least with respect to the Academy of Noble Arts of Mexico City at the beginning of the nineteenth century, is shared by Humboldt in several passages of his famous Ensayo politico del reino de la Nueva España (Humboldt, 1822-1991, pp. 7980 and 457). The institution, co-financed by the administration and civil society, is presented as a model of socioeconomic and racial, and even gender inclusiveness. ${ }^{27}$ Its teachings pursued the enlightened ideal of combining the search for-classical- beauty and the practical application of knowledge.

We agree with Crayen and Baten (2012) that numeracy increased during the eighteenth century in New Spain -as well as in other Iberian American countries- and also that this allowed convergence in numeracy -if only partial- with the most advanced countries. This trend forcibly reduced inequality in heaping and therefore in human capital formation. We also concur with Crayen and Baten (2012) in that the improvement stopped by the early nineteenth century and especially -we add- after 1810. Evidence shown by these two authors and others (e.g., Staples, 2011) suggests that, as in other aspects of the Mexican socioeconomic conditions, the notion of "lost decades" after independence makes sense. This view of the long-term evolution of

\footnotetext{
${ }^{27}$ For instance, Guadalupe de Moncada y Berrio, the daughter of the Marquesses of Moncada, attended the Academy of Fine Arts. She decorated with tempera some of the rooms of the palace of her grandmother, the Countess of San Mateo Valparaíso.
} 
education in Iberian America is also consistent with Newland (1991, p. 92) since he claims that the "growth in the supply and demand of education in the last part of the eighteenth century" was discontinued until the "next significant expansion of education" which occurred "during the second half of the next century".

Some Indian communities seem to have been the major losers due to the institutional and economic changes after independence and this situation negatively affected their education (Tanck, 1999; Staples, 2011). As to the Church's educational activities, many of the free public schools sustained by ecclesiastical institutions were closed as a consequence of the depletion of the resources of the Church produced by the Consolidación de Vales Reales decree (1804) and the war of independence (18101821).

Finally, a preliminary assessment of the relationship between human capital proxied by basic numeracy skills- and GDP per capita can be presented. According to the specialized literature, a positive correlation exists between numeracy-measured by age heaping- and economic growth (e.g., Crayen and Baten, 2010a) while causality is usually assumed to go from the latter to the former. In Figure 3, the (log) GDP per capita estimated by Maddison for 1870 is plotted against age heaping circa 1820 taken from Tallnek and Baten (2017). The sample includes 26 countries from Europe and America -see Figure 3-. ${ }^{28}$ Mexican age heaping is the weighted average of our three subsamples.

\footnotetext{
${ }^{28}$ Argentina, Austria, Belgium, Bulgaria, Canada, Czechoslovakia, Denmark, Finland, France, Germany, Hungary, Italy, the Netherlands, Norway, Poland, Romania, Sweden, Switzerland, the United Kingdom, Ireland, Greece, Mexico, Portugal, Spain, the USA, and Uruguay.
} 


\section{ABCC (heaping) 1820 vs Maddison GDP 1870}

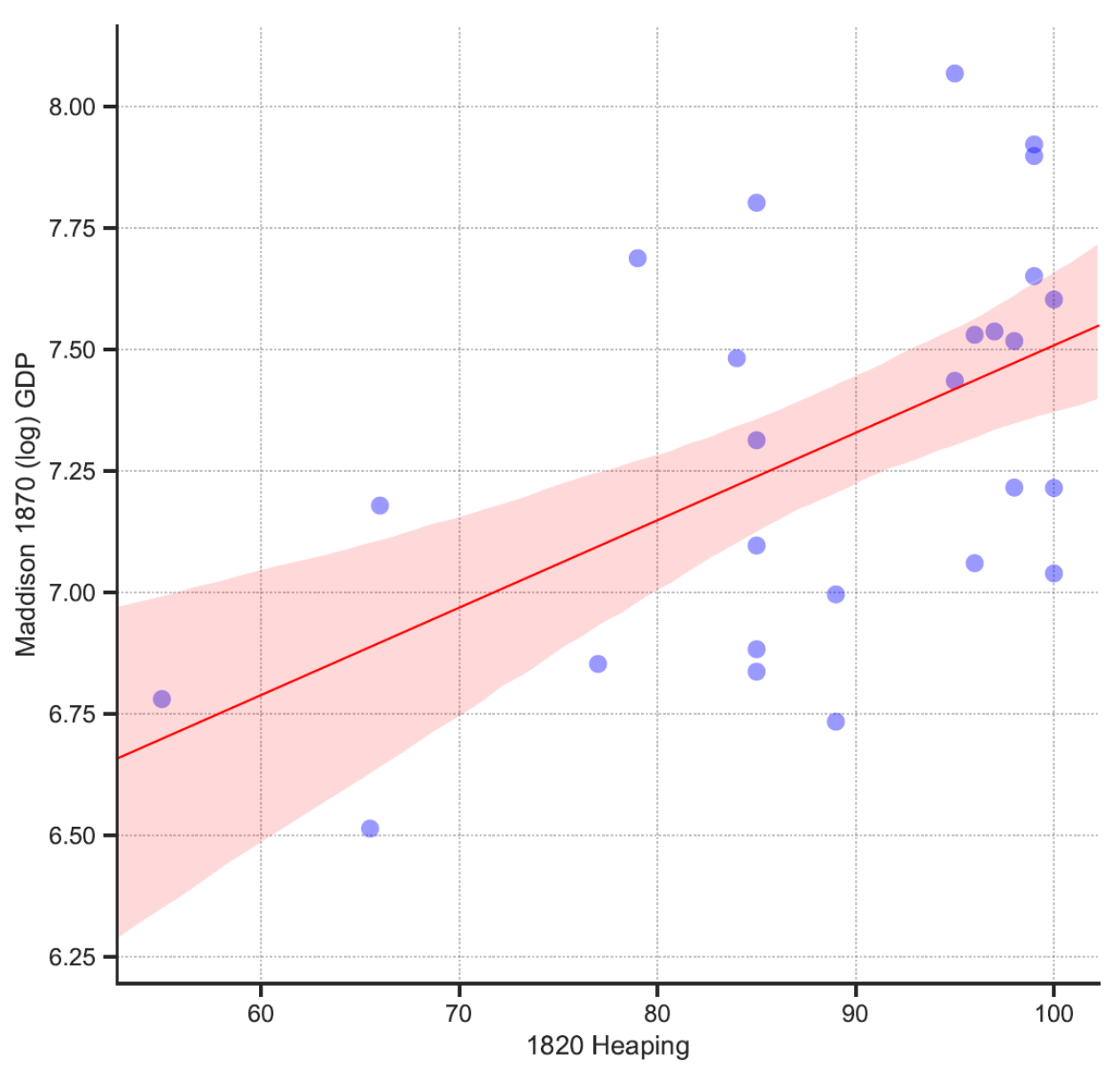

Source: Tollnek and Baten, (2017) and Maddison

(http://www.ggdc.net/maddison/oriindex.htm)

A positive and significant relationship between age heaping in 1820 and (log) GDP per capita exists for 1820 . The linear relation is slightly stronger (in terms of Rsquared and significance) if we regress (log) GDP per capita for 1870 on age heaping circa $1820 .{ }^{29}$ We interpret this result as evidence suggesting that Granger causality (Granger, 1980) goes from human capital to economic growth rather than the other

\footnotetext{
${ }^{29}$ Estimates by Maddison prove to be more consistent than those provided by the Maddison Project 2018 (https://www.rug.nl/ggdc/historicaldevelopment/maddison/releases/). Was the GDP per capita higher in Spain than in the Netherlands in early nineteenth century? Or was it lower in many European countries or in Mexico than in South Africa? It is doubtful. To check the robustness of outliers of the results, we run $n$ regression with $n-1$ observations, removing one observation each time. For every regression the results do not change in terms of terms of $\mathrm{R}$-squared and significance of the coefficients.
} 
way around. Building on the results of this model, the residuals offer useful insights on Mexico's comparative situation -see Figure 4-.

FIGURE 4

Maddison GDP o/ E(GDP|heaping) in \%

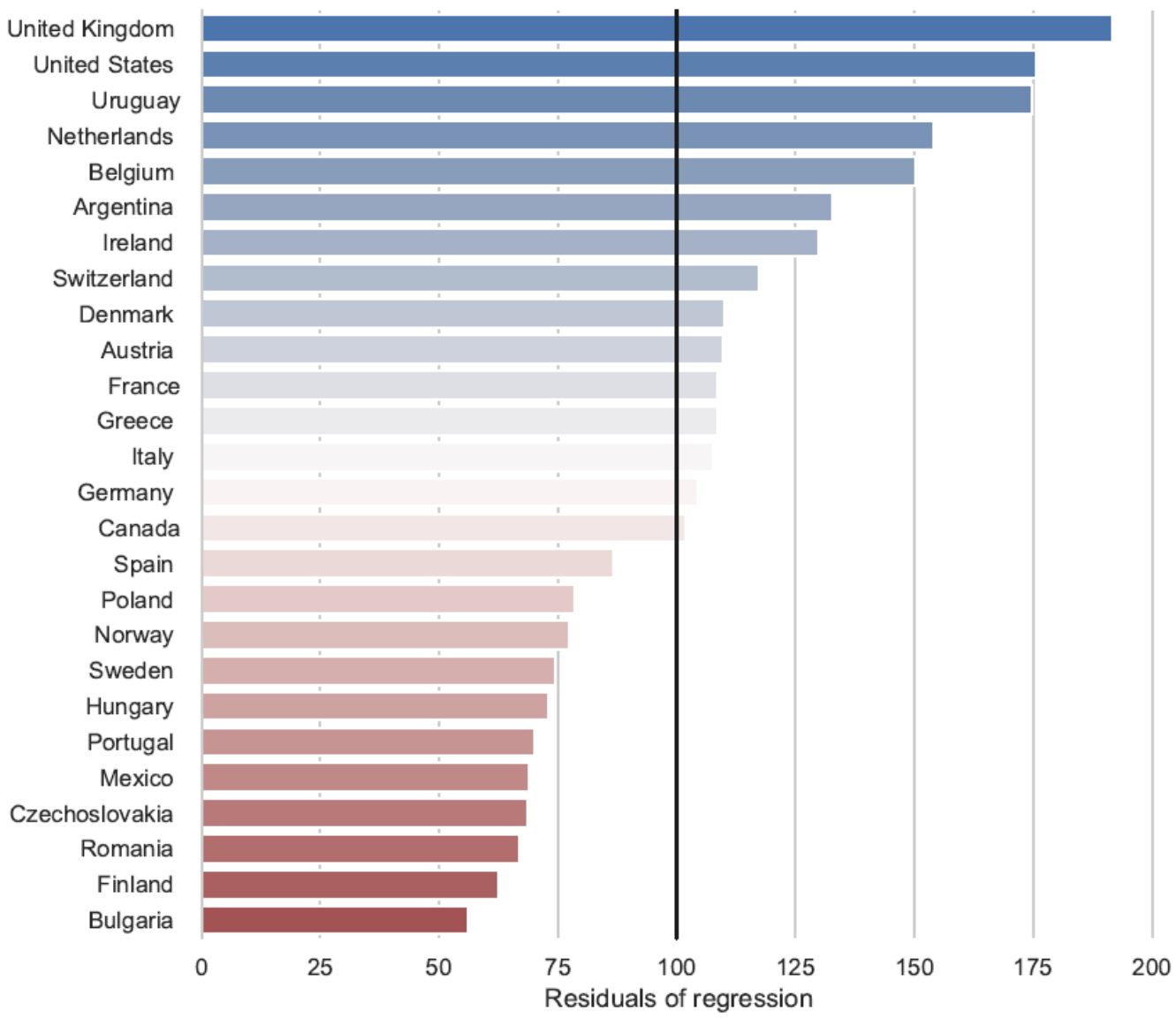

How to read this figure:

Example 1: UK residuals of 190 means that Maddison UK 1870's GDP p.c. was $90 \%$ greater than the expected GDP p.c. given UK 1820's heaping.

Example 2: Bulgaria residuals of 56 means that Maddison Bulgaria 1870 's GDP p.c. was $44 \%$ lower than the expected GDP p.c. given Bulgaria 1820's heaping.

Source: See Figure 3.

Mexico belongs to the group of countries whose 1870 (log) GDP per capita was significantly lower than those conditional to heaping in the 1820s. Along with Mexico, all sorts of European countries (Catholic as well as Protestant and Orthodox) show up in this group of underperformers. By 1870, Mexican GDP per capita was clearly lower 
than the level that can be predicted in accordance to its numeracy fifty years before. ${ }^{30}$ Can Mexico be considered a proper case of a literate poor country? This possibility will be explored in depth in further research.

\section{FINAL REMARKS}

The main results from our quantitative empirical research on numeracy in late preindependent Mexico may be summarized as follows. Numeracy, proxied by age heaping, is similar to that of peripheral Europe and much lower than in most backward countries from other continents. Spatial differences in numeracy may be observed, as is the case across European regions. As we had previously assumed, ethnicity was highly significant. Thus, inequalities based on ethnicity are found. Españoles were at the top of the distribution, indios and mulatos (or negros) at the bottom and other castas in between. However, these disparities, which may also be viewed from a socioeconomic perspective, were not significantly larger than those found in developed countries from the seventeenth to the nineteenth centuries, not to mention the Cape Colony. Geographical heterogeneity might counterbalance ethnicity as an explanatory factor of inequalities. A sexual divide may be seen, but no higher than in European samples for different periods and even sometimes favoring some female communities (e.g., Oaxaca). Circa 1870, Mexican GDP per capita was below the level that might be expected from the numeracy reached before independence.

The types and intensity of the inequalities in numeracy do not convert New Spain into an outlier in terms of human capital formation and its distribution in the preindustrial era. Clear progress, and hence convergence with the leaders, was achieved through the eighteenth century by increasing schooling in both the república de indios and the república de españoles. This progress was interrupted in 1804-1810, when the effects of the Consolidación of Vales Reales was reinforced by the beginning of the Insurgencia war. The improvement of human capital formation did not resume until the last quarter of the nineteenth century.

\footnotetext{
${ }^{30}$ The regression using the estimates of the Maddison Project 2018 yields less significant (although still at a $10 \%$ level) results. However, by doing this, Mexico becomes an even clearer case of negative residual.
} 
Our results have implications regarding the (dominant) pessimistic view of the Spanish "colonial legacy" in terms of backwardness and inequality. Our findings show a society with better levels of human capital formation than those probably assumed by the mainstream historiography; taking numeracy as an indicator, late eighteenthcentury New Spain was clearly closer to the most advanced countries than to the rest of the world. This is particularly true for some locations of the central regions of the Viceroyalty.

Initial and persistent differences in human capital seem to have a significant explanatory potential of the diverse economic performance of individuals, ethnic groups, sexes, social classes, and territories throughout Spanish America.

The pre-Hispanic legacy should not be disregarded as one of the factors explaining the comparative low level of numeracy among indios to which the isolation of many of their pueblos probably also contributed significantly.

Inequality in numeracy was, as in almost every preindustrial society, a reality; a fact which is more often than not forgotten. In this respect, empirically unfounded generalizations are particularly mistaken. Studying numeracy allows us to conclude that New Spain had little or nothing to do with the dual vision presented by the dominant scholarship (a few rich, exploitative Spaniards versus innumerable, poor, exploited Indians). The actual society of New Spain was much more complex. In the words of a reputed specialist:

"The reality of the [Spanish] American colonial world differs, thus, of the prevailing image of a society composed by a few dominators and a lot of dominated ones". (Carmagnani, 2004, p. 87. Our translation).

Received February 20 2 th 2019 . Accepted September $17^{\text {th }}, 2019$.

\section{ACKNOWLEDGEMENTS}

The authors thank three anonymous referees and the editors for their comments and suggestions. Andrés Calderón-Fernández thanks the postdoctoral research fellowship programme of Mexico's National University (Programa de Becas Posdoctorales UNAM - DGAPA) that has funded his research since August 2018. Rafael Dobado-González has received financial support from the Spanish Ministry of Economy and Competitiveness (ECO2014-58250-P). Alfredo Garcia-Hiernaux acknowledges funding from UCMSantander PR75/18-21570. We also thank our research assistants in this project: 
Violeta Barrientos Nieto, Gerardo Saldaña Domínguez and, in particular, María Luisa Domínguez (Universidad de Sevilla).

\section{REFERENCES}

ACEMOGLU, D., JOHNSON, S. and ROBINSON, J. A. (2001): "The Colonial Origins of Comparative Development: An Empirical Investigation", American Economic Review 91 (5), pp. 1369-1401.

ACEMOGLU, D., JOHNSON, S. and ROBINSON, J. A. (2002): "Reversal of Fortune: Geography and Development in the Making of the Modern World Income Distribution", Quarterly Journal of Economics 117 (4), pp. 1231-1294.

A'HEARN, B., BATEN, J. and CRAYEN, D. (2009): “Quantifying Quantitative Literacy: Age Heaping and the History of the Human Capital", The Journal of Economic History 69 (3), pp. 783-808.

A'HEARN, B., DELFINO, A. and NUVOLARI, A. (2016): "Rethinking Age-Heaping. A Cautionary Tale from Nineteenth Century Italy", LEM Papers Series, 35, Laboratory of Economics and Management (LEM), Sant'Anna School of Advanced Studies, Pisa.

ÁlVAREZ, B. and RAMOS PALENCIA, F. (2018): "Human capital and earnings in eighteenth-century" Explorations in Economic History, 67, pp. 105-133.

ARROM, S. M. (1988): Las mujeres de la ciudad de México, 1790-1857, México City: Siglo XXI.

ARROYO ABAD, L. and LUITEN VAN ZANDEN, J. (2016): "Growth under Extractive Institutions? Latin America Per Capita GDP in Colonial Times", The Journal of Economic History 76 (4), pp. 1182-1215.

ARROYO ABAD, L., DAVIES, E. and LUITEN VAN ZANDEN, J. (2012): "Between Conquest and Independence: Real Wages and Demographic change in Spanish America 1530-1820", Explorations in Economic History 49 (2), pp. 149-166.

BATEN, J. and FOURIE, J. (2015): "Numeracy of Africans, Asians, and Europeans during the Early Modern Period: New Evidence from Cape Colony Court Registers", Economic History Review 68 (2), pp. 632-656.

BATEN, J., MAB, D., MORGAN, S. and WANGA, Q. (2010): "Evolution of Living Standards and Human Capital in China in the 18-20th Centuries: Evidences from Real Wages, Age-heaping, and Anthropometrics", Explorations in Economic History, 47, pp. 347-359.

BATEN, J. and MUMME, C. (2010): "Globalization and Educational Inequality during the 18th to 20th centuries: Latin America in Global Comparison", Revista de Historia Económica/Journal of Iberian and Latin American Economic History 28 (2), pp. 279-305. 
BATEN, J. and SOHN, K. (2017): "Numeracy in Early Modern Korea, Japan, and China: The Age-heaping Approach" Japan and the World Economy, 43, pp. 14-22.

BELTRÁN, F. J., DÍEZ, A., MARTINEZ, J. and TIRADO, D. A. (2018): "Two Stories, One Fate: Age-heaping and Literacy in Spain, 1877-1930," Working Papers 0139, European Historical Economics Society (EHES).

BLUM, M., and KRAUSS, K. P. (2018): “Age Heaping and Numeracy: Looking behind the Curtain", Economic History Review 71 (2) pp. 464-479.

CALDERÓN, A. (2009): "Una serie de precios de vivienda. Las accesorias del Real Colegio de San Ignacio de Loyola de los Señores Vizcaínos, 1771-1821", Gaceta Vizcaínas 4, pp. 47-83.

CALDERÓN, A. (2016): “Alquileres, salarios y consumos. Una revaluación de los ingresos y niveles de vida de los habitantes de la capital del reino de la Nueva España", torales, M. C. (ed.), Nueva España en la Monarquía Hispánica, siglos XVI$X I X$, miradas varias, San Luis Potosí-México D. F : El Colegio de San LuisUniversidad Iberoamericana, pp. 355-377.

CALDERÓN, A. and DOBADO, R. (2012): "Siete mitos acerca de la historia económica del mundo hispánico", Calderón, A. and Dobado, R. (eds.), Pintura de los Reinos. Identidades compartidas en el mundo hispánico. Siglos XVI al XIX, Mexico City: Fomento Cultural Banamex, pp. 75-103.

CARMAGNANI, M. (2004): El otro occidente. América Latina desde la invasión europea hasta la globalización, Mexico City: Fondo de Cultura Económica

COATSWORTH, J. H. (2005): "Structures, Endowments, and Institutions in the Economic History of Latin America", Latin America Research Review 40(3), pp. 126-144.

COATSWORTH, J.H. (2008): "Inequality, Institutions and Economic Growth in Latin America”, Journal of Latin American Studies 40, pp. 545-569.

COOK, S. F. and BORAH, W. (1977-1980): Ensayos sobre historia de la población: México y el Caribe, 3 vols., Mexico: Siglo XXI.

CRAYEN, D. and BATEN, J. (2010a): "Global Trends in Numeracy 1820-1949 and its Implications for Long-term Growth", Explorations in Economic History 47, pp. 8299.

CRAYEN, D. and BATEN, J. (2010b): "New Evidence and New Methods to Measure Human Capital Inequality Before and During the Industrial Revolution: France and the US in the Seventeenth to Nineteenth Centuries", Economic History Review 63 (2), pp. 452-478.

DJENDEREDJIAN, J. and MARTIRÉN, J. L. (2015): “Precios, producto agrario y niveles de vida en las fronteras rioplatenses, 1700-1810: una nueva mirada sobre el crecimiento económico tardocolonial", Revista de Historia Económica, Journal of Iberian and Latin American Economic History 33, 1, pp. 123-152. 
DE MOOR, T. and LUITEN VAN ZANDEN, J. (2010a): "Every Woman Counts. A Gender Analysis of Numeracy in the Low Countries During the Early Modern Period", The Journal of Interdisciplinary History 41 (2), pp. 179-208.

DE MOOR, T. and LUITEN VAN ZANDEN, J. (2010b): "Girl Power: the European Marriage Pattern and Labour Markets in the North Sea Region in the Late Medieval and Early Modern Period", Economic History Review 63 (1), pp. 1-33.

DOBADO, R. (2009): “Herencia colonial y desarrollo económico en Iberoamérica: una crítica a la 'nueva ortodoxia'", in Llopis, E. and Marichal, C. (eds.), Latinoamérica y España, 1800-1850. Un crecimiento económico nada excepcional, Madrid: Marcial Pons and Instituto Mora, pp. 253-291.

DOBADO, R. (2010): "Prices and Wages in Bourbon Mexico from an International Comparative Perspective", in Morilla, J., Hernandéz Andreu, J., García Ruiz, J. L. and Ortiz-Villajos, J. M. (eds.), Homenaje a Gabriel Tortella. Las claves del desarrollo económico y social, Madrid: LID and Universidad de Alcalá, pp. 85-102.

DOBADO, R. and GARCÍA HIERNAUX, A. (2017): "Two Worlds Apart: Determinants of Height in Late 18th Century Central Mexico", Economics and Human Biology 24, pp. 153-163.

DOBADO, R. and GARCÍA-MONTERO, H. (2010): "Colonial Origins of Inequality in Hispanic America? Some Reflections Based on New Empirical Evidence", Revista de Historia Económica/Journal of Iberian and Latin American Economic History 28 (2), pp. 253-277.

DOBADO, R. and GARCÍA-MONTERO, H. (2014): "Neither So Low No So Short: Wages and Heights in Bourbon Spanish America from an International Comparative Perspective", Journal of Latin American Studies 46, pp. 291-321.

DOBADO, R. and GARCÍA-MONTERO, H. (2015): "El bienestar económico y biológico en la América borbónica: una comparación internacional de salarios y estaturas", in Gelman, J., Llopis, E. and Marichal, C. (eds.), Iberoamérica y España antes de las independencias, 1700-1820: el impacto económico de las reformas borbónicas y pombalinas, y de las guerras napoleónicas, Mexico City: Instituto Mora and El Colegio de México, pp. 481-524.

DOBADO, R. and MARRERO, G. (2001): "Minería, crecimiento económico y costes de la independencia en México", Revista de Historia Económica 19 (3), pp. 573-611.

DOBADO, R. and MARRERO, G. (2014): “El 'Mining-Led Growth' en el México borbónico, el papel del Estado y el coste económico de la Independencia", in Hausberger, B. and Ibarra, A. (coords.), El comercio mundial de la plata y del oro: Estudios comparativos. Siglos XVI-XIX, Mexico City: El Colegio de México and UNAM, pp. 177-216.

ENGERMAN, S. L. and SOKOLOFF, K. (1994): "Factor Endowments, Institutions, and Differential Paths of Growth Among New World Economies" NBER Historical Paper No. 66. 
ENGERMAN, S. L. and SOKOLOFF, K. (2002): "Factor Endowments, Inequality, and Paths of Development Among New World Economies", NBER Working Paper No. 9259.

ENGERMAN, S. L. and SOKOLOFF, K. (2005): "Colonialism, inequality, and Long-Run Paths of Development", NBER Working Paper 11057.

GLAESER, E. L., LA PORTA, R., LÓPEZ DE SILANES and SHLEIFFER, A. (2004): "Do Institutions Cause Growth?", Journal of Economic Growth 9, pp. 271-303.

GÓMEZ AZNAR, E. (2019): "Human Capital at the Beginning of the 18th century Catalonia: Age-heaping and Numeracy in a Changing Economy", DT-AEHE №1904, Asociación Española de Historia Económica.

GONZALBO AIZPURU, P. (2000): Historia de la educación en la época colonial. El mundo indígena, Mexico City: El Colegio de México.

GRANGER, C.W.J. (1980). "Testing for Causality: A Personal Viewpoint", Journal of Economic Dynamics and Control 2, pp. 329-352.

HAUSBERGER, B. and MAZíN, O. (2010) "Nueva España: los años de autonomía", in Nueva Historia General de México, México D.F.: El Colegio de México, pp. 263-306.

HIPPE, R. (2012): "How to Measure Human Capital? The Relationship Between Numeracy and Literacy", Economies et Sociétés 46 (8), pp. 1627-1654.

HIPPE, R. and BATEN, J. (2011): "Regional Inequality in Human Capital Formation in Europe, 1790-1880", Working Paper, 7, Association Française de Cliométrie.

JUIF, D. T. and BATEN, J. (2013): "On the Human Capital of Inca Indios Before and After the Spanish Conquest. Was there a "Pre-Colonial Legacy"?", Explorations in Economic History 50 (2), pp. 227-241.

JUIF, D.T, BATEN, J. and PÉREZ-ARTES, M.C. "Numeracy of Religious Minorities in Spain and Portugal during the Inquisition Era", Revista de Historia Económica/Journal of Iberian and Latin American Economic History, forthcoming.

LLORCA, M., NAVARRETE, J., DROLLER, F. and ARAYA, R. (2018): Economics and Human Biology 29, pp. 168-178.

LOMBARDO, S., DE LA TORRE, G., GAYÓN, M. Y MORALES, M. D. (2009): Territorio y demarcación en los censos de población. Ciudad de México 1753, 1790, 1848 y 1882, México D.F.: Instituto Nacional de Antropología e Historia

MANZEL, K. (2009): Essays on Human Capital Development in Latin America and Spain, PhD Dissertation, Eberhard Karls Universität Tübingen.

MANZEL, K. and BATEN, J. (2009): "Gender Equality and Inequality in Numeracy: The Case of Latin America and the Caribbean, 1880-1949," Revista de Historia Económica/Journal of Iberian and Latin American Economic History 27 (1), pp. 3773. 
MANZEL, K., BATEN, J. and STOLZ, Y. (2012): "Convergence and Divergence of Numeracy: The Development of Age Heaping in Latin America from the Seventeenth to the Twentieth Century," The Economic History Review, 65 (3), pp. 932-960.

MARICHAL, C. (2007): Bankruptcy of Empire: Mexican Silver and the Wars between Spain, Britain and France, 1760-1810, New York: Cambridge Latin American Studies

MILANOVIC, B., LINDERT, P. H. and WILLIAMSON, J. G. (2011): "Preindustrial Inequality", The Economic Journal 121, pp. 255-272.

MORAES, M. I. and THUL, F. 2018): "Los salarios reales y el nivel de vida en una economía latinoamericana colonial: Montevideo entre 1760-1810", Revista de Historia Económica/Journal of Iberian and Latin American Economic History 36, 2, pp. 185-213.

NEWLAND, C. (1991): "Spanish American Elementary Education Before Independence: Continuity and Change in a Colonial Environment", Itinerario 15 (2), pp. 79-95.

PÉREZ TOLEDO, S. and KLEIN, H. (2004): "Perfil demográfico y social de la Ciudad de México en 1790. Evaluación de tres zonas contrastantes", in Miño, M. and Pérez Toledo, S., La población de la Ciudad de México en 1790. Estructura social, alimentación y vivienda, Mexico D.F: Universidad Autónoma Metropolitana, El Colegio de México and CONACYT, pp. 75-114.

PLATT, L. D. (1998): Census Records for Latin America and the Hispanic United States, Baltimore, MD.: Genealogical Publishing Co.

SÁNCHEZ SANTIRÓ, E. (2004a): "La población de la ciudad de México en 1777", Secuencia 60, pp. 31-56.

SÁNCHEZ SANTIRÓ, E. (2004b): "El nuevo orden parroquial de la Ciudad de México: población, etnia y territorio, 1768-1777", Estudios de Historia Novohispana 30, pp. 63-92.

SÁNCHEZ SANTIRÓ, E. (2007): “El legado económico del Antiguo Régimen colonial novohispano", in Dobado, R., Gómez, A. and Márquez, G. (comps.), México y España ¿Historias económicas paralelas?", Mexico D.F.: Fondo de Cultura Económica,pp. 137-182.

STAPLES, A. (2011): "El entusiasmo por la Independencia", in Tanck, D. (coord.), Historia mínima. La educación en México, Mexico City: El Colegio de México, pp. 97-126.

TANCK, D. (1998): La educación ilustrada, 1786-1836. Educación primaria en la ciudad de México, Mexico City: El Colegio de México.

TANCK, D. (1999): Pueblos de indios y educación en el México colonial, 1750-1821, Mexico City: El Colegio de México 
TANCK, D. (2011): "El Siglo de las Luces", in Tanck, D. (coord.), Historia mínima. La educación en México, Mexico City: El Colegio de México pp. 67-96.

TANCK DE ESTRADA, D. and MARICHAL, C. (2010): “¿Reino o Colonia? Nueva España, 1750-1804", Nueva Historia General de México, Mexico D.F.: El Colegio de México, pp. 307-353.

TORALES PACHECO, M. C. (2001): Ilustrados en la Nueva España: los socios de la Real Sociedad Bascongada de los Amigos del País, Mexico City: Universidad Iberoamericana.

TOLLNEK, F. and BATEN, J. (2017): "Farmers at the Heart of the 'Human Capital Revolution'? Decomposing the Numeracy Increase in Early Modern Europe", Economic History Review 70 (3), pp. 779-809.

VERA BOLAÑOS, M. (2004): "La composición de la familia en la ciudad de México en 1790. Una reconstrucción demográfica", in Miño, M. and Pérez Toledo, S., La población de la Ciudad de México en 1790. Estructura social, alimentación y vivienda, Mexico City: Universidad Autónoma Metropolitana, El Colegio de México and CONACYT, pp. 115-145.

WILLIAMSON, J. G. (2009): "Five Centuries of Latin American Inequality", NBER Working Paper 15305. 


\section{APPENDIX}

The Whipple index $(W)$ is a statistical measure that proxies for numeracy based on the accuracy of the age reported by a population. Mathematically, it is formulated as:

$W=500\left(\frac{n_{25}+n_{80}+\cdots+n_{60}}{n_{28}+n_{24}+\cdots+n_{61}+n_{62}}\right)$, where $n_{a}$ is the number of people declaring age $a$.

In broad terms, an index value of 0 indicates that nobody in the population reported an age multiple of 5 , a value of 100 means no heaping (the proportion of multiples of 5 are those expected) and a value of 500 means perfect heaping (only ages multiples of 5 were reported). So, Whipple values sufficiently greater than 100 evidence heaping and lack of numeracy.

The Whipple Index is probably the most common indicator for numeracy as it does not depend on the size of the population and can then be used for comparison purposes. However, some researchers also used the so-called, $A B C C$ Index, named after A'Hearn, Baten and Crayen (2009) and Gregory Clark. The ABCC formula is based on the Whipple Index and is calculated as:

$A B C C=100\left(1-\frac{W-100}{400}\right)$, for $W \geq 100$ and $A B C C=100$ in any other case.

The aim of the $A B C C$ is to offer an index bounded between 0-100, which can then be interpreted as the share of individuals that correctly report their age as a percentage.

The relation between both indexes is depicted in the following figure showing that Whipple values of 100,300 and 500 correspond to $100 \%, 50 \%$ and $0 \%$ of individuals that correctly report their age ( $A B C C$ interpretation), respectively.

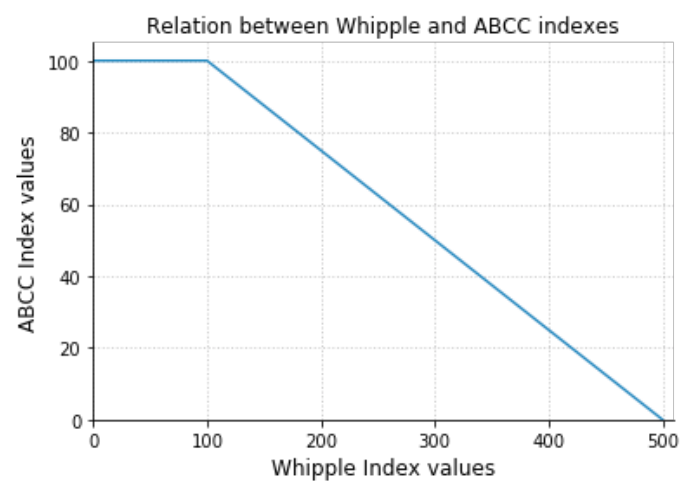

One index is a linear transformation of the other and so they have the same properties, while the interpretation is a slightly different. In this paper both indices are used in order to make the results comparable with all studies of the subject. 